\title{
THE INTER-AMERICAN AND EUROPEAN CONTEXTS OF HUMAN RIGHTS PROTECTION: A BRIEF COMPARATIVE ANALYSIS OF REGIONAL COURTS' DECISIONS
}

\section{OS CONTEXTOS INTERAMERICANO E EUROPEU DE PROTEÇÃO DOS DIREITOS HUMANOS: UMA BREVE ANÁLISE COMPARATIVA DAS DECISÕES DAS CORTES REGIONAIS}

\author{
Melina Girardi Fachin* \\ Ilton Norberto Robl Filho** \\ Fabricio Ricardo de Limas Tomio***
}

\begin{abstract}
Regional systems of human rights are part of a complex protective system that also includes national and global instruments. One of the important advantages of regional systems in comparison with global protection instruments of human rights lies in the lower difficulty of those systems in establishing consensus on these rights. Undeniably, the Inter-American and European systems are the most structured and developed and are specific object of analysis in this paper. After a reflection on the construction of the International Law of Human Rights and the Inter-American Human Rights System, this paper presents the empirical research data of the Inter-American Court of Human Rights from 2006 to 2012. Subsequently, performs a comparison with the judgments made by the European Court of Human Rights in the 2009-2015 period. It is important to register that this article uses, besides specialized literature, a strong comparative approach between American and European Human Rights Systems and, especially, techniques of empirical legal studies with a large number (Large-N) of data. The hypothesis to be tested in this text is that American and European Systems has many peculiarities because of the cultural, legal, and historical circumstances, but a comparative study of those systems is important to understand some common problems and to analyze different ways to deal with the protection of human rights. As will be showed in this paper, the hypothesis is true because, for example, the number of processes is very diverse, but both systems have strong problems in correctly enforcing their decisions.
\end{abstract}

\section{KEYWORDS}

Human rights. Regional systems. Regional courts. Comparison.

\footnotetext{
* Adjunct Professor at the Federal University of Paraná (UFPR), Brazil, School of Law. Ph.D in Law from PUC/SP. Email: melinafachin@gmail.com

** Adjunct Professor at the Federal University of Paraná (UFPR) and at the University of Passo Fundo (UPF), Brazil, School of Law. Ph.D in Law from UFPR. E-mail: norbertorobl@gmail.com

*** Associate Professor at the Federal University of Paraná (UFPR), Brazil, School of Law. Ph.D in Political Science from Unicamp. E-mail: fab_tom@hotmail.com

This research was conducted at the Research Center "DIRPOL - Law and Politics" (PPGD / UFPR) with funding from the CNPq (Edital 14/2014). Research project: "Political institutions, legislative and abstract judicial review: comparative study of executive relations / legislature, the Constitutional Jurisdiction and legislative production in the sub-national units" and the Research Group Constitutional Jurisdiction and Democracy (PGGD / UPF). A preliminary version of the article was presented at the VIII International Conference on the occasions of 50th anniversary of signing of the International Covenants on Human Rights and 35th anniversary of signing of the African Charter of Human and Peoples' Rights (2016, Warsaw, Poland). We thank the panelists for the comments. Any inaccuracies are the sole responsibility of the authors.
} 


\section{RESUMO}

Os sistemas regionais de proteção aos direitos humanos inserem-se em complexo mecanismo protetivo composto também por mecanismos nacionais e globais. Uma das importantes vantagens dos sistemas regionais em comparação com instrumentos globais de proteção aos direitos humanos reside na menor dificuldade daqueles sistemas em firmar consensos sobre esses direitos. Inegavelmente, os sistemas interamericano e europeu são os mais estruturados e desenvolvidos, sendo objeto de análise específica neste trabalho. Após uma reflexão sobre a construção do Direito Internacional dos Direito Humanos e o Sistema Interamericano de Direitos Humanos, apresentam-se os dados de pesquisa empírica sobre as decisões da Corte Interamericana de Direitos Humanos no período de 2006 a 2012. Posteriormente, realiza-se uma comparação com os julgamentos produzidos pela Corte Europeia de Direitos Humanos no período de 2009 a 2015. É importante registrar que este artigo utiliza, além de literatura especializada, uma forte análise comparativa entre os sistemas americano e europeu de direitos humanos e, em especial, técnicas de estudos legais empíricos com um grande número (Large- $N$ ) de dados. A hipótese a ser testada consiste na afirmação de que os sistemas americano e europeu possuem muitas peculiaridades por circunstâncias culturais, legais e históricas, mas um estudo comparativo desses sistemas é relevante para compreender alguns problemas comuns e para analisar diferentes formas de realizar a proteção dos direitos humanos. Como será demonstrado no artigo, a hipótese é verdadeira porque, por exemplo, o número de processos é muito diverso, mas ambos os sistemas têm fortes problemas para fazer cumprir adequadamente suas decisões.

\section{PALAVRAS-CHAVE}

Direitos humanos. Sistemas regionais. Cortes regionais. Comparação.

\section{INTRODUCTION}

At the present time, when it comes to protecting human rights, it is imperative to add the facet of international law to the constitutional-state aspect.

The contemporary conception of human rights, along with the process of intensification of constitutional protection, is marked by the international protection of human person, a recent phenomenon that dates from the post-World War II. It was the atrocities, in the context of the worldwide conflict, which led to the need, alongside the national systems, for an international willingness to protection and the emergence of the so-called international human rights law.

The protection of human rights has become a topic of international interest, not only in the domestic sphere, bearing in mind the consequences and scope that it can produce. This is the context that provides the foundation for the consolidation of an international legal system of human rights protection (along with and also in limitation ${ }^{1}$ of constitutional-state orders) that connects to international obligations due to the respect, protection and realization of human rights along with (and

\footnotetext{
${ }^{1}$ On the subject, see: ARENDT, Hannah. As origens do totalitarismo. São Paulo: Companhia das Letras, 1989; LAFER, Celso. A reconstrução histórica dos direitos humanos. São Paulo: Companhia das Letras, 1998.
}

Revista da Faculdade de Direito - UFPR, Curitiba, vol. 61, n. 3, set./dez. 2016, p. 67 - 89 
also in limitation ${ }^{2}$ of) constitutional-state orders to international obligations due to the respect, protection and realization of human rights ${ }^{3}$.

The international legal system of human rights is thus emerged. The first step was the creation of the United Nations which opened, at international level, a new stage with the structure represented by their organizations and specialized agencies, based on broad reach treaties on the matter.

In this context, the Universal Declaration of Human Rights opens a new paradigm - practical and theoretical - of human rights ${ }^{4}$. Not without criticism, the Declaration aimed at establishing a new international order based on the respect for human dignity through basic universal values ${ }^{5,6}$.

Thus, motivated by the Declaration's legacy, and with the intention of giving greater institutionality to the subject, alongside the global system under the leadership of the UN, emerge three institutionalized regional human rights systems in European, inter-American and African regions, in addition to the incipient Arab and Asian systems.

It is emerged a "new public order"7, whose function is to develop a "legal policy"8 with repercussions both on the internal legal order and on the international legal order.

The regional systems have the advantage of an easier consensus, given a smaller number of states, and a smaller cultural disparity. Moreover, today, the regional systems have competent jurisdiction on human rights subjects, especially with highlights to American and European experiences.

Each regional protection system develops according to its conditions and peculiarities, but,

\footnotetext{
${ }^{2}$ Flávia Piovesan says, "it was emerged the certainty that the protection of human rights should not be reduced to a reserved State area, as it reveals a legitimate issue of international interest. In this light, the violation of human rights cannot be conceived as a State's domestic issue, but as an international relevant problem, as a legitimate concern of the international community.” (PIOVESAN, Flávia. Direitos humanos e o direito constitucional internacional. 13. ed. São Paulo: Saraiva, 2012. p. 185).

3 HENKIN, Louis. International law: politics, values and functions. In: STEINER, Henry J.; ALSTON, Philip. International human rights in context. 2nd ed. Oxford: Oxford University Press, 2000. p. 127.

${ }^{4}$ CANÇADO TRINDADE, Antônio Augusto. O legado da declaração universal e o futuro da proteção internacional dos direitos humanos. In: AMARAL JUNIOR, Alberto; PERRONE-MOISÉS, Claudia (Org.). O Cinquentenário da Declaração Universal dos Direitos do Homem. São Paulo: Edusp, 1998.

5 “All cultures have conceptions of human dignity, but not all of them conceive it in terms of human rights." (SANTOS, Boaventura de Sousa. Por uma concepção multicultural de direitos humanos. In: caminhos do cosmopolitismo multicultural. Rio de Janeiro: Civilização Brasileira, 2003. p. 442)

${ }^{6}$ About this common trait says Kwame Anthony Appiah: “[...] starting with our common biology and the shared problems of human situation (and granted that we may also share cultural traits because of our common origins), human societies have ended up having many deep things in common.” (APPIAH, Kwame Anthony. Cosmopolitanism: ethics in a world of strangers. New York: W.W. Norton \& Company, 2006. p. 96).

${ }^{7}$ BOGDANDY, Armin von; PIOVESAN, Flávia; ANTONIAZZI, Mariela Morales (Coord.). Estudos avançados em direitos humanos: democracia e integração jurídica: emergência de um novo direito público. São Paulo: Campus, 2012.

${ }^{8}$ LAFER, Celso. Comércio, desarmamento e direitos humanos: reflexões sobre uma experiência diplomática. São Paulo: Paz e Terra, 1999. p. 179.
} 
all in its path, contribute to the strengthening of international human rights legal system.

One important tool to human rights international jurisdictions is to dialogue with each other. The experiences of one system can contribute to the development of the other, no matter on what sense: global-regional; regional-regional; global-local; regional-local. The dynamic effects of protection go beyond the borders of the systems which are permeable among each other. In this sense is Jorge Rodrigues-Zapata lesson:

It can be seen from the Constantine and Benjamin Hilaire v. Trinidad and Tobago judgment of 21 June 2002 of the Inter-American Court of Human Rights (in San José, Costa Rica), on the death penalty, that the European Convention on Human Rights is part of a global common law. [...] The Supreme Court of the United States, in its Atkins v. Virginia judgment of 20 June 2002, on the death penalty for mentally retarded persons, or in Lawrence et al. v. Texas of 26 June 2003, on intimate homosexual relations between adults as a criminal offence, referred to the judgment of the European Court of Human Rights in Dudgeon v. the United Kingdom. In Spain, decisions nos. 64/2001 (of 17 March 2001) and 2/2003 (of 19 February 2003) of the Constitutional Court referred to the Fifth Amendment to the United States Constitution and the prohibition of double jeopardy and to Protocol No. 7 to the European Convention on Human Rights, even though Spain is not a party to this Protocol and it is not binding on us. This is important: even though Spain is not a party to this Protocol and it is not binding on us $^{9}$.

The focus is to understand the new space that opens to the constitutional law on the new framework of Public Law in the XXI century, marked by dialogue between the different protection (global-regional-local) systems and the impact of international human rights law in national constitutional systems. The protection of human rights - and as a consequence the consolidation of democracy and the rule of law - emerges as a common language pointing to rethink the structures and the space of constitutional law and the adaptation of international law in order to promote transit of legal institutions and categories of a legal system to another. All this on behalf of more protection for groups and individuals.

Dialogues and perspectives on protection systems should take into account the premise of universality - and not the uniformity - of human rights. It is about the American and European contexts that the present study intends to focus. Although not ignoring the existence of values that not all communities recognize as valid, there is, in this post-1948 sense, the identification, according to our common origin, of a shared axiological code. This is the basis for the universalist discourse rooted on the respect for human dignity through basic universal values. Dialogues in this tone rhyme with the understanding of the other and recognition of difference. The different systems interact,

\footnotetext{
${ }^{9}$ PÉREZ, Jorge Rodrigues-Zapata. The dynamic effect of the case-law of the European Court of Human Rights and the role of the constitutional courts. In: EUROPEAN COURT OF HUMAN RIGHTS. Dialogues between judges. Strasbourg: Council of Europe, 2007. Available from: https://goo.gl/nWxakh [Accessed: June 2012].
}

Revista da Faculdade de Direito - UFPR, Curitiba, vol. 61, n. 3, set./dez. 2016, p. 67 - 89 
putting differences to light and bringing the need for communicative action on behalf of the pro persona clause.

By the method, this article uses, besides a theoretical framework and an analysis of specialized literature, a comparative approach between American and European Human Rights Systems and, specially, techniques of empirical legal studies with a large number (Large-N) of data ${ }^{10}$. The hypotheses to be tested in this text is that American and European Systems has many peculiarities because of the cultural, legal and historical conditions, but a comparative study of those systems is important to understand some common problems and to analyze different ways to deal with the protection of human rights.

The main purpose of this article is to present a panoramic view of American and European systems of Human Rights specially with actualized data about processes and instruments of protection. The paper's structure contains this introduction, a presentation of the Inter-American Human Rights System in section 1, some comparisons and relations between the European Court and Inter-American Court of Human Rights in section 2 and conclusion in the final section.

\section{THE INTER-AMERICAN HUMAN RIGHTS SYSTEM}

The American system is quite peculiar because it rests on a dual basis: on the one hand, it is based on the American Convention on Human Rights, so-called Pact of San José, Costa Rica, which has been in force since 1978; on the other hand, the Charter of the Organization of American States which was adopted in 1948. The duality has persisted to the present day especially considering that there is substantial divergence in the signatory countries of these two regional documents of international law.

All members of the Organization of American States ${ }^{11,12}$ are subject to the jurisdiction of the Commission which consists of seven experts; it has jurisdiction accessible to all individuals and non-governmental bodies in member countries ${ }^{13}$. Today, it is the main drive body of the Inter-

\footnotetext{
10 About comparative constitutional law and empirical legal studies, see HIRSCHL, Ran. The rise of comparative constitutional law: thoughts on substance and method. Indian Journal of Constitutional Law, p. 11-38, 2008.

${ }^{11}$ Argentina, Bolivia, Brazil, Chile, Colombia, Costa Rica, Cuba, Ecuador, El Salvador, United States, Guatemala, Haiti, Honduras, Mexico, Nicaragua, Panama, Paraguay, Peru, Dominican Republic, Uruguay, and Venezuela signed the OAS Charter and subsequently ratified it.

12 On the other hand, 14 countries ratified the aforementioned Convention thereafter: Barbados, Trinidad and Tobago, Jamaica, Grenada, Suriname, Dominica, St. Lucia, Antigua and Barbuda, Saint Vincent and the Grenadines, Bahamas, St. Kitts and Nevis, Canada, Belize, and Guiana.

13 "In the 1965, the petition system was formalized and expanded at the Second Special Inter-American Conference [...] the Commission could examine communications submitted to it, but this possibility was restricted to a number of essential human rights.” WILT, Harmen van der; KRSTICEVIC, Viviana. The OAS system and human rights. In: HANSKI, Raija;
} 
American Court of Human Rights, since only the Inter-American Commission or the State members may submit a dispute to the Court.

The Commission on Human Rights, in this context, has as its primary aim to promote the protection of human rights in the Americas. For the pursuit of its goal, the Committees' main functions are to: receive petitions from individual complaints, make reports on the situation of human rights in member states, and propose measures to strengthen human rights in the region.

All member countries of the OAS are submitted to the system of human rights protection as stated in art. 106 of the OAS Charter, mainly based on the observance of the rights and duties in the American Declaration of the Rights and Duties of Man of $1948^{14}$.

It is possible to present individual petition to the Inter-American Commission on Human Rights (IACHR) against alleged human rights violations committed in all OAS member countries in the system adopted by the OAS Charter, in terms of article 36.

About the emergence of this body, clarifies Antônio Cançado Trindade, Judge of the InterAmerican Court of Human Rights:

\begin{abstract}
Created (in 1959) by a resolution (rather than a treaty), the Inter-American Commission on Human Rights had originally a mandate limited to the promotion of human rights and enjoyed a sui generis position within the inter-American system. Soon it endeavored to enlarge its own competence, as an organ of in loco investigation of situations of human rights and of examination of communications of alleges violations of human rights. Its enlarged attributions and powers were also to comprise the reporting system (reports of distinct kinds, such as session and annual reports, and reports on specific countries). With the 1967 Protocol of Reform of the OAS Charter (which entered into force in 1970) the Commission was at last established as one of the main organs of the OAS and thus endowed with a conventional basis. Ever since it has had a duality of functions, namely, vis-a-vis States Parties to the American Convention as well as States not Parties to the Convention (as to these latter, on the basis of OAS Charter and 1948 American Declaration) ${ }^{15}$.
\end{abstract}

On the other hand, countries that have not ratified the American Convention on Human Rights and did not recognize the national character of the Inter-American Court of Human Rights, the OAS Charter system does not allow referral of case to the Court, having less effectiveness (enforcement).

SUKSI, Markku. An introduction to the international protection of human rights. 2nd ed. Turku: Institute for Human Rights, Åbo Akademi University, 2004. p. 372.

14 "Chapter XV. INTER-AMERICAN COMMISSION ON HUMAN RIGHTS. Article 106. There shall be an InterAmerican Commission on Human Rights, whose principal function shall be to promote the observance and protection of human rights and to serve as a consultative organ of the Organization in these matters. An inter-American convention on human rights shall determine the structure, competence, and procedure of this Commission, as well as those of other organs responsible for these matters”.

${ }^{15}$ CANÇADO TRINDADE, Antônio Augusto. The Inter-American System of Protection of Human Rights (1948-2005): evolution, present state and perspectives. In: Apostila do curso fundamental em inglês do instituto Internacional dos Direitos do Homem, sessão de 4-29 de julho de 2005, p. 53. 
In turn, the American Convention on Human Rights came into force in 1978, setting in addition to the Inter-American Commission on Human Rights, the existence of the Inter-American Court of Human Rights. In the protection system established under the American Convention, all individuals, groups and non-governmental organization may present petitions of individual cases referred to the Commission due to alleged violations committed in the States Parties, according to art. 45 of the $\mathrm{ACHR}^{16}$.

In relation to the Court structure clarifies Flávia Piovesan: "In regard to the Inter-American Court, the court of regional system, it is composed of seven national member states judges of the OAS, elected by indication of each States Parties of the Convention"17.

As in the European model, the Inter-American Court has dual expertise: contentious - as an extension of analyzing petitions already initiated by the Commission - and consultative, the latter much more developed than in the old continent, which shows the peculiarity of regional systems.

About the Court’s activities, explains Cançado Trindade:

For the exercise of the Court's contentious jurisdiction, a declaration of acceptance is required from States Parties to the American Convention. In its turn, the advisory jurisdiction is particularly wide, given that all OAS member States and all organs mentioned in the chapter X of the OAS Charter can request advisory opinions from the Court on distinct topics (e.g., interpretation of the American Convention or of other treaties relating to the protection of human rights in the American States with the American Convention or other human rights treaties). The Court has also been developing, in recent years, a remarkable practice on provisional or interim measures of protection ${ }^{18}$.

Out of the 23 States Parties, only Grenada and Jamaica do not recognize the national character (litigation) of the Inter-American Court of Human Rights.

The Inter-American system rests mainly on the American Convention on Human Rights, the surnamed Pact of San José, Costa Rica, adopted in 1969 and in force since 1978. After to list vast array of civil and political rights (Articles 3 to 25), the American Convention shows improvement on the European model, but still insufficiently. There is a generic clause forecasting social rights that intones the progressivity of implementation, linking them to available resources of States.

In order to complement the protection of social rights in the Americas, only in 1988 it was

\footnotetext{
16 Argentina, Barbados, Bolivia, Brazil, Chile, Colombia, Costa Rica, Dominican Republic, El Salvador, Grenada, Guatemala, Haiti, Honduras, Jamaica, Mexico, Nicaragua, Panama, Paraguay, Peru, Dominican Republic, Suriname, and Uruguay ratified the ACHR, whereas Venezuela and Trinidad and Tobago denounced the ACHR.

${ }^{17}$ PIOVESAN, Flávia. Direitos humanos e justiça internacional. São Paulo: Saraiva, 2006, p. 98.

${ }^{18}$ CANÇADO TRINDADE, Antônio Augusto. The Inter-American System of Protection of Human Rights (1948-2005): evolution, present state and perspectives. In: Apostila do curso fundamental em inglês do Instituto Internacional dos Direitos do Homem, sessão de 4-29 de julho de 2005, p. 58.
} 
approved the San Salvador Protocol, setting out rights to social welfare and bringing an expanded inventory of economic, social and cultural ranges from labor guarantees, trade union rights and social security guarantees including the right to health, education, culture, among many others, the exception of environmental rights not contemplated herein.

However, as the global and European systems, except for the right to education and the right to freedom of association under Article 19, § 6, also need international enforceability it is outside the jurisdiction of the Inter-American Court of Human Rights.

Nevertheless, despite the liberal catalogue of rights, it is important to notice the jurisprudence of the IACHR's characterizing the Convention as a living instrument - influenced by the European Court understanding, to include within its scope the indirect protection of economic, social, and cultural. Evolutive interpretation, as applied by the European Court, aims to contextualize the intended protection, keeping them alive and connected to reality and to the surrounding demands. Based on this IACHR's - and even European Court of Human Rights, more timidly - have rescued the protection of social rights, even indirectly.

The Inter-American System, by its context and violations is much more invasive than that European, guided by the margin of appreciation doctrine. On the other hand, the IACHR's decisions may set the recovery of the damages of material and immaterial harms, in addition to imposing all the measures to promote the enjoyment and recovery to the consequences of rights violation in accordance pursuant to art. 63.1, IACHR.

Table 1. Inter-American Court of Human Rights (IACHR, final judgment)

\begin{tabular}{|c|c|c|c|c|c|c|c|c|c|}
\hline Judgments (IACHR) & 2013 & 2012 & 2011 & 2010 & 2009 & 2008 & 2007 & 2006 & Total \\
\hline $\begin{array}{l}\text { Judgments finding at least } \\
\text { one violation }\end{array}$ & 16 & 17 & 15 & 9 & 17 & 14 & 11 & 22 & 121 \\
\hline $\begin{array}{l}\text { Judgments finding no } \\
\text { violation }\end{array}$ & & 2 & 1 & & & 4 & 1 & 1 & 9 \\
\hline $\begin{array}{l}\text { Friendly settlements / } \\
\text { striking-out judgments }\end{array}$ & & 2 & 1 & & & & & & 3 \\
\hline $\begin{array}{l}\text { Other judgments / not } \\
\text { specified }\end{array}$ & & & 1 & & 2 & & & & 3 \\
\hline Total & 16 & 21 & 18 & 9 & 19 & 18 & 12 & 23 & 136 \\
\hline
\end{tabular}

The table above shows the small number of cases analyzed by the Inter-American Court of Human Rights, although it exercises its jurisdiction over 550 million people in 21 States Parties. The 
number of cases presented to the IACHR differs to the huge volume of petitions submitted to the Inter-American Commission, namely, it was 2,061 in 2013 and 1,936 in $2012^{19}$. On the other hand, the Commission only referred to the Court 11 cases in 2013 and 12 in 2012. Thus, André de Carvalho Ramos properly argues: "The actions filed by the Commission before the Inter-American Court of Human rights are rare and, since the Court has entered into operation in 1978 to the present day, there have been about 170 contentions cases”20.

Still, precautionary and emergency injunctions and measures (provisional measures) may be drawn up by the IACHR before the final judgment of the case, thereby seeking to avoid irreparable damage in cases of extreme gravity, according to art. 63.2 of the IACHR. These precautionary measures are granted when a case is already under the Court's analysis or when it is requested by the Inter-American Commission on Human Rights. As shown below, 309 provisional measures were judged by the Court in the period between 2006 and 2013, being this number about 250\% higher than the final judgments formally drawn up by the Commission.

Table 2. Inter-American Court of Human Rights (IACHR, MP - Precautionary Measures)

\begin{tabular}{lccccccccc}
\hline $\begin{array}{l}\text { MP - Granted / Requests } \\
\text { (IACHR) }\end{array}$ & $\mathbf{2 0 1 3}$ & $\mathbf{2 0 1 2}$ & $\mathbf{2 0 1 1}$ & $\mathbf{2 0 1 0}$ & $\mathbf{2 0 0 9}$ & $\mathbf{2 0 0 8}$ & $\mathbf{2 0 0 7}$ & $\mathbf{2 0 0 6}$ & Total \\
\hline $\begin{array}{l}\text { Judgments finding at least } \\
\text { one violation }\end{array}$ & 17 & 25 & 47 & 29 & 39 & 29 & 27 & 35 & 248 \\
\hline $\begin{array}{l}\text { Judgments finding no } \\
\text { violation }\end{array}$ & & 11 & 8 & 7 & 6 & 2 & 8 & 4 & 46 \\
\hline $\begin{array}{l}\text { Friendly settlements / } \\
\text { striking-out judgments }\end{array}$ & & & 1 & 1 & 1 & & & 3 \\
\hline $\begin{array}{l}\text { Other judgments / not } \\
\text { specified }\end{array}$ & 8 & & & 2 & & & 1 & 1 & 12 \\
\hline $\begin{array}{l}\text { Total } \\
\text { Source: Inter-Amm }\end{array}$ & 25 & 36 & 55 & 39 & 46 & 32 & 36 & 40 & 309 \\
\hline
\end{tabular}

Source: Inter-American Court of Human Rights - Jurisprudence. https://goo.gl/qBgcOC [Accessed Sep. 15, 2015]. Database organized by the research group (DIRPOL/PPGD/UFPR).

19 INTERAMERICAN COMISSION OF HUMAN RIGHTS. Statistics. Available from: https://goo.gl/8CSqBE [Accessed: Apr. 2016].

${ }^{20}$ RAMOS, André de Carvalho. Processo internacional de direitos humanos. 4. ed. Saraiva: São Paulo, 2015 , p. 267. 
Graph 1. IACHR (Precautionary Measures, by year)

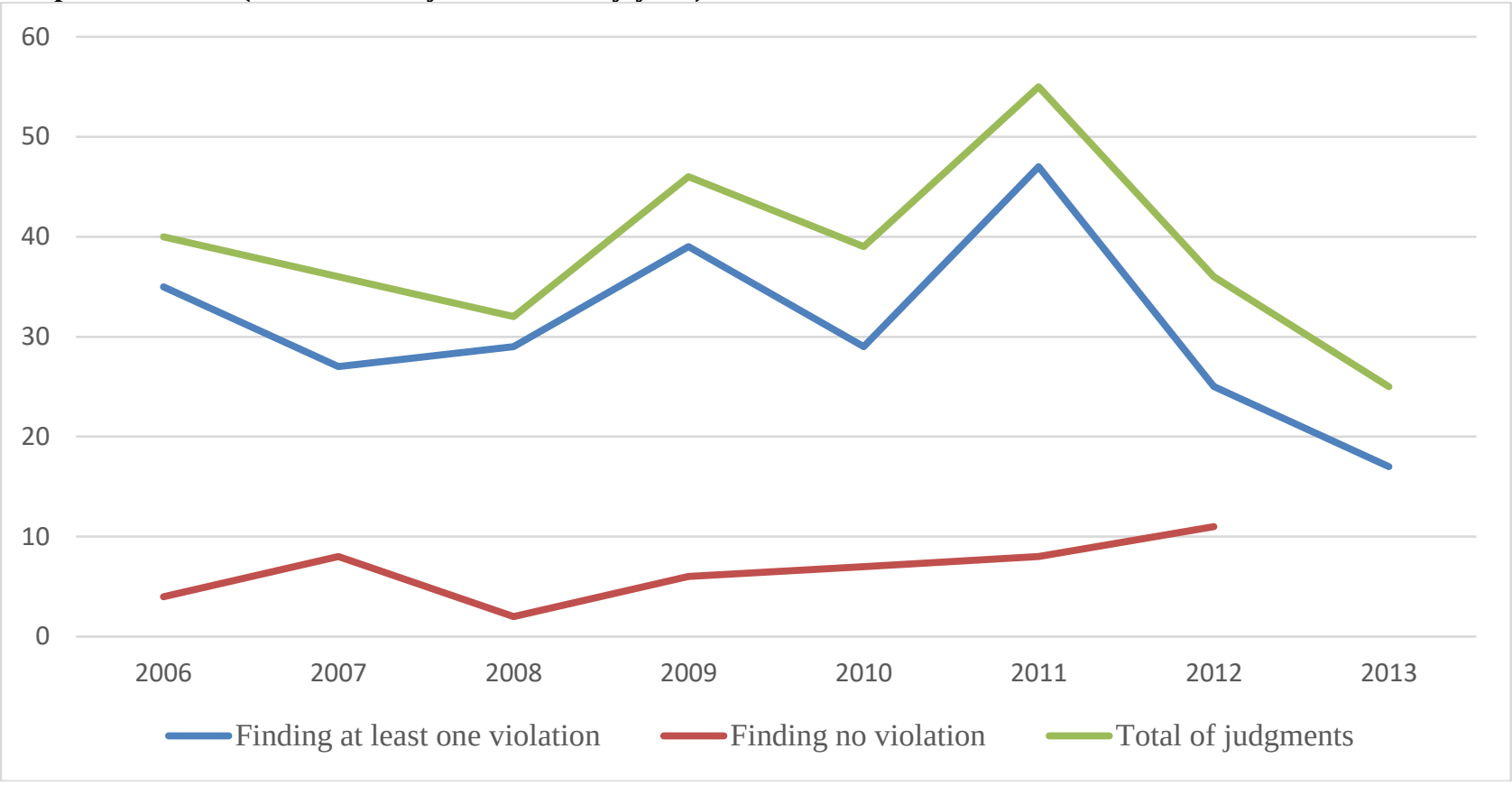

Graph 2. IACHR (Precautionary Measures, 2006-2013)

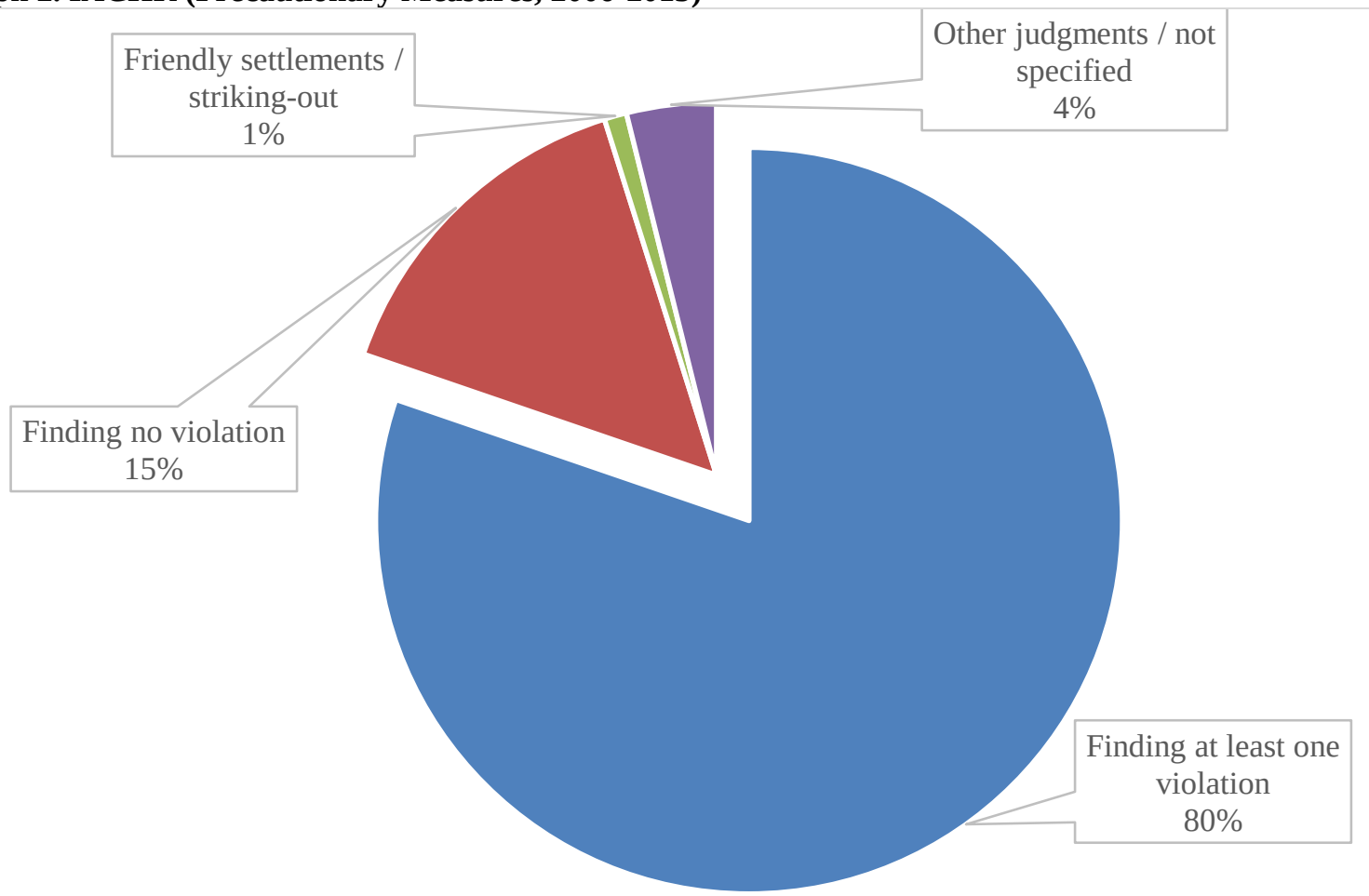

On the one hand, it is undeniable that the Inter-American System of Human Rights was inspired by the European Human Rights System, but there are structural and political peculiarities, in 
both models, which make considerable differences ${ }^{21}$.

\section{SOME COMPARISONS AND RELATIONS BETWEEN THE EUROPEAN COURT AND INTER-AMERICAN COURT OF HUMAN RIGHTS}

Firstly, there has been a higher amount of demands presented to the European Human Rights compared to the Inter-American System for several reasons.

Beside the UN system, European regional system of protection of human rights is one of the most structured and old. Just as it was with the overall structure emerges as a means of counterpoint humanitarian violations committed during the Second World War.

The European Court of Human Rights is provided for in Articles 19 and following of the European Convention on Human Rights, adopted on 4 November 1950 by the Council of Europe, in order to ensure compliance with the international commitments made by States Parties, particularly in human rights.

The Court consists of a number of judges equal to the total of the signatories of the treaty and is located in Strasbourg in France. In view of the expansion of the Council of Europe since the adoption of the Convention the number of States Parties almost quadrupled. About this shift, teaches J. G. Merrills:

Since the Convention was signed in 1950, membership of the Council of Europe has quadrupled and there has been a corresponding increase in the number of parties to the Convention. This expansion, and in particular the general acceptance of the right of individual application under article 25, generated an ever increasing work load for the Strasbourg institutions. Contributing factors were the dynamic approach of the Commission and the Court to the interpretation of the Convention, which along with the conclusion of new protocols, widened its protection, and the dissemination of knowledge about the Convention, which has encouraged more and more people to explore its possibilities. The developments are, of course, an indication of the Convention's success. But they have also put its institutional machinery under increasing strain and raised the question of how it can be adapted to cope with the new situation. [... $]^{22}$

Currently, the European Convention of Human Rights and Fundamental Freedoms of 1950

\footnotetext{
21 “[...] the inter-American system for the protection of human rights has developed [...] in ways that mirror the European system of human rights protection. However, the Interamerican system has distinguished itself from the other regional or global systems [...].” (WILT, Harmen van der; KRSTICEVIC, Viviana. The OAS System and Human Rights. In: HANSKI, Raija; SUKSI, Markku. An introduction to the international protection of human rights. 2nd ed. Turku: Institute for Human Rights, Åbo Akademi University, 2004. p. 371).

${ }^{22}$ MERRILLS, J. G. The Council of Europe (I): The European Convention on Human Rights. In: HANSKI, Raija; SUKSI, Markku. An Introduction to the International Protection of Human Rights. 2nd ed. Turku: Institute for Human Rights, Åbo Akademi University, 2004. p. 299.
} 
has been ratified by 47 countries and exercises jurisdiction over 880 million people. The Optional Protocol. 11 (P-11), which entered into force in 1998, abolished the European Commission on Human Rights and allowed the presentation of individual complaints directly to the European Court of Human Rights by victims.

Table 3. European Court of Human Rights (ECHR)

\begin{tabular}{|c|c|c|c|c|c|c|c|c|c|c|}
\hline $\begin{array}{l}\text { Judgments } \\
\text { (ECHR) }\end{array}$ & 2015 & 2014 & 2013 & 2012 & 2011 & 2010 & 2009 & $\begin{array}{l}\text { Total } \\
(2009- \\
2015)\end{array}$ & $\begin{array}{c}\% \\
(2009- \\
2015 \text { / } \\
1959- \\
2015) \\
\end{array}$ & $\begin{array}{c}\text { Total } \\
(1959- \\
2015)\end{array}$ \\
\hline $\begin{array}{l}\text { Judgments } \\
\text { finding at least } \\
\text { one violation }\end{array}$ & 694 & 756 & 797 & 899 & 987 & 1.282 & 1.504 & 6.919 & $44 \%$ & 15.570 \\
\hline $\begin{array}{l}\text { Judgments } \\
\text { finding no } \\
\text { violation }\end{array}$ & 100 & 101 & 96 & 144 & 122 & 107 & 83 & 753 & $55 \%$ & 1.357 \\
\hline $\begin{array}{l}\text { Friendly } \\
\text { settlements / } \\
\text { striking-out } \\
\text { judgments } \\
\end{array}$ & 8 & 4 & 5 & 9 & 4 & 3 & 10 & 43 & $4 \%$ & 1.080 \\
\hline $\begin{array}{l}\text { Other judgments } \\
\text { (1) }\end{array}$ & 25 & 35 & 21 & 151 & 52 & 108 & 30 & 422 & $69 \%$ & 613 \\
\hline Total & 827 & 896 & 919 & 1.203 & 1.165 & 1.500 & 1.627 & 8.137 & $44 \%$ & 18.620 \\
\hline
\end{tabular}

This change had a great impact on the European system, as the period from 14 November 1960 until the Commission's dissolution, only 837 cases were judged by the European Court (Strasbourg), thus the Commission was able to filter about 45,000 petitions presented in this period. On the other hand, 10 years after the European Commission's extinction, the Court celebrated the judgment of 10,000 cases. In fact, in the recent period from 2009 to 2015, 8,137 cases were judged by the European Court of Human Rights ${ }^{23}$.

\footnotetext{
${ }^{23}$ RAMOS, André de Carvalho. Processo internacional de direitos humanos. 4. ed. Saraiva: São Paulo, 2015 , p. 171.
} 
Graph 3. ECHR (Judgments, by year)

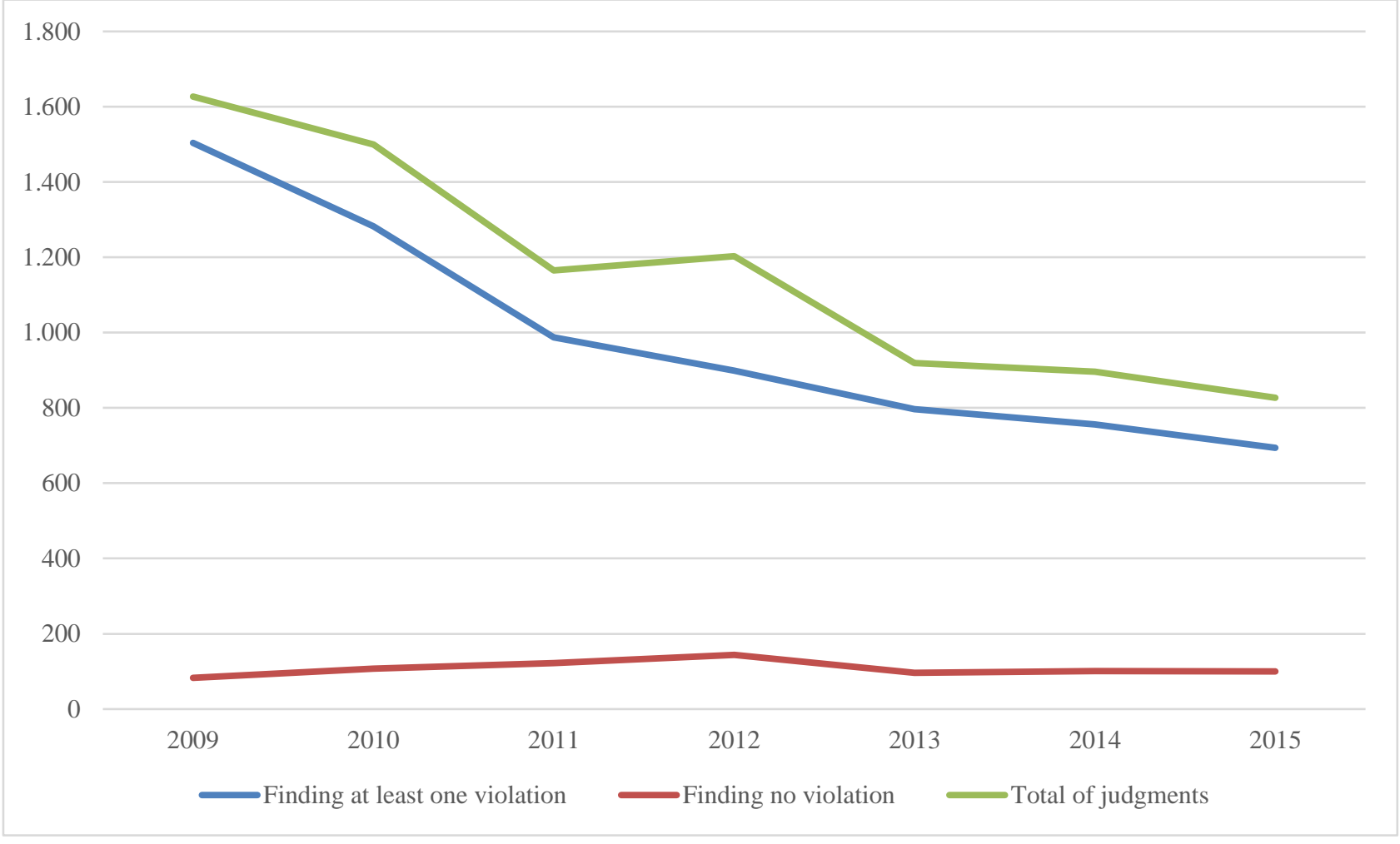

Graph 4. ECHR (Judgments, 2009-2015)

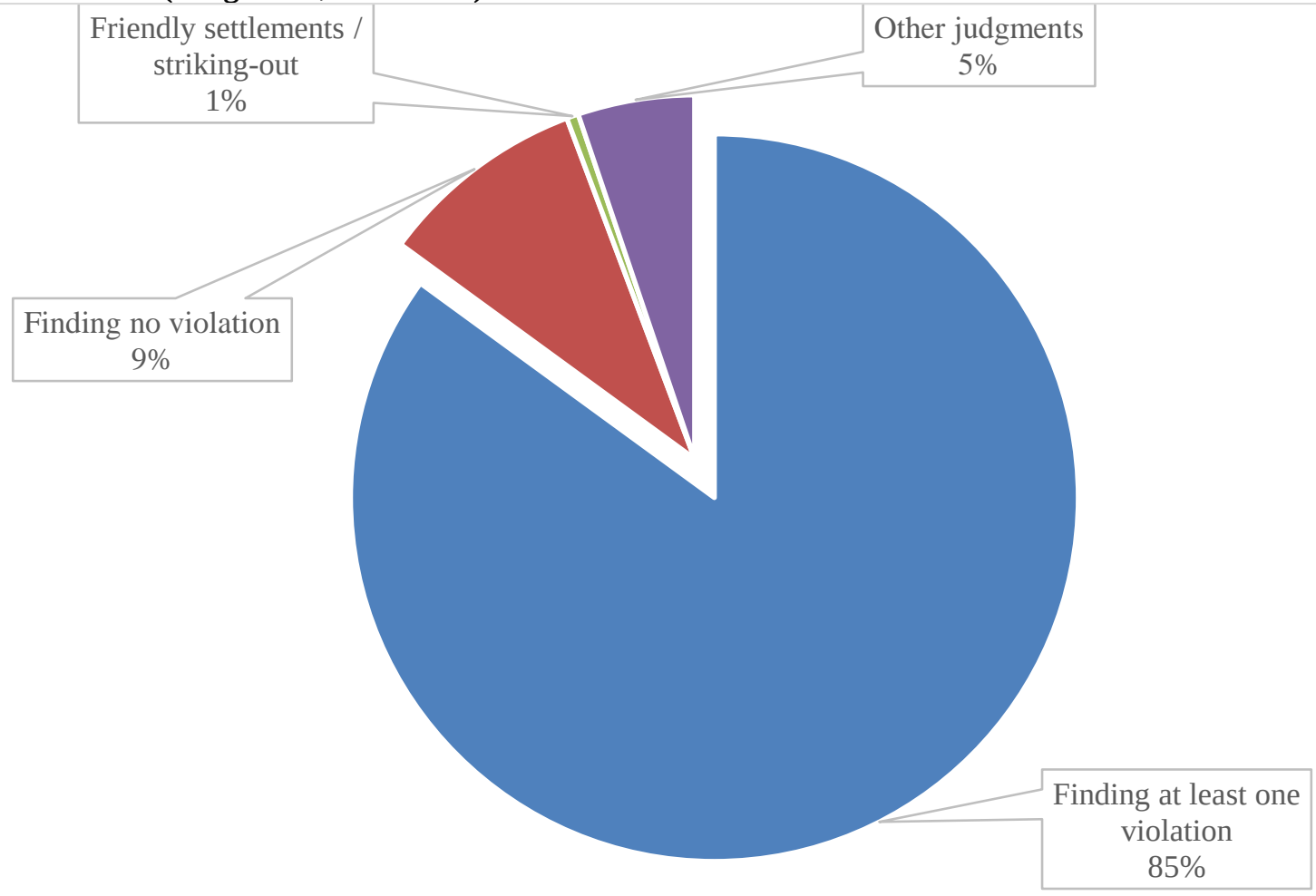

There was a gradual reduction in the number of cases examined by the European Court from 2009 to 2015. Prior to the change in the structure of the European system, there were several cases 
that were not analyzed by the Court in Strasbourg due to the strong exercise of discretion in accepting a case imposed by the Commission. In turn, with the end of the need for victims to submit their claims to the Commission, there was a lawsuit explosion in the Court, which has declined somewhat recently. This small reduction in demand is explained by contained litigation, as well as the change in exercising judgments by the European Court, which attacked the repetitive suits with instruments such as the pilot-judgment procedure, according to which from an individual case, the Court determines general measures to prevent and protect all similar cases.

Thus, as all persons who are in the territory of the 47 States Parties of the European Convention have direct access to the European Court, and since only 21 out of the 35 American countries recognize Court's jurisdictional character and yet bearing in mind that individuals submit cases to the Court without a preliminary analysis of the Inter-American Commission, there is a huge difference in the number of cases examined by the two Regional Courts of Human rights.

Table 4. Comparative - European Court of Human Rights (ECHR) / Inter-American Court of Human Rights (IACHR)

\begin{tabular}{|c|c|c|c|c|}
\hline \multirow[b]{2}{*}{ Judgments } & (ECHR) & \multicolumn{3}{|c|}{ (IACHR) } \\
\hline & $\begin{array}{l}\text { Judgments } \\
\text { (2009-2015) } \\
\end{array}$ & $\begin{array}{c}\text { Final } \\
\text { Judgments } \\
(2006-2013) \\
\end{array}$ & $\begin{array}{c}\text { Precautionary } \\
\text { Measures Granted } \\
\text { (MP) / Requests } \\
(2006-2013) \\
\end{array}$ & $\begin{array}{l}\text { Total } \\
(2006- \\
2013)\end{array}$ \\
\hline $\begin{array}{l}\text { Judgments finding at least } \\
\text { one violation }\end{array}$ & 6.919 & 121 & 248 & 369 \\
\hline $\begin{array}{l}\text { Judgments finding no } \\
\text { violation }\end{array}$ & 753 & 9 & 46 & 55 \\
\hline $\begin{array}{l}\text { Friendly settlements / } \\
\text { Striking-out judgments }\end{array}$ & 43 & 3 & 3 & 6 \\
\hline Other judgments (1) & 422 & 3 & 12 & 15 \\
\hline Total & 8.137 & 136 & 309 & 445 \\
\hline
\end{tabular}

Source: Inter-American Court of Human Rights - Jurisprudence. https://goo.gl/qBgcOC [Accessed Sep. 15, 2015]; European Court of Human Rights - Statistics. https://goo.gl/okFnH [Accessed Apr. 3, 2016 ]. Database organized by the research group (DIRPOL/PPGD/UFPR). 


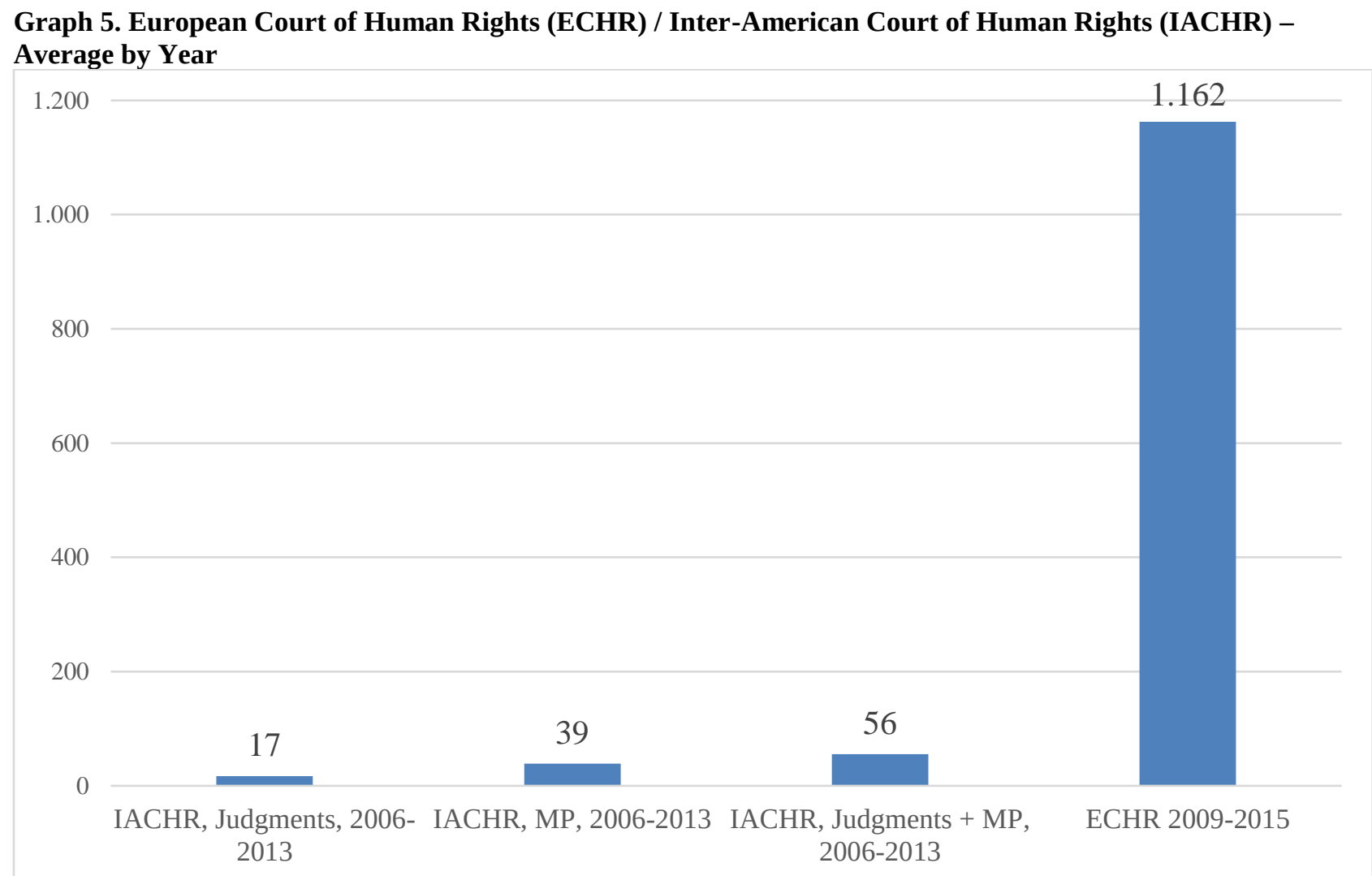

Yet, the issues faced by American Human Rights Courts and European diverge substantially. The American system has been addressing basic questions of human and fundamental rights, through judgment of several lawsuits that deal with four major categories, according to the systematization of notable doctrine: 1 . violations that still reflect the legacy of the dictatorial regime and challenges on the strengthening of institutions and of the rule of law; 2. issues relating to transitional justice; 3. rights violations of vulnerable groups and, finally, 4. indirect litigation of social rights.

The first category refers to the common challenge of strengthening institutions and the consolidation of the rule of law that the region countries still face with the most basic and barbarous violations of rights committed by state agents, imposing limitations on it. A noteworthy example is the leading case Velasquez Rodriguez versus Honduras concerning the enforced disappearance in 1989.

The second group deals with the issue of transitional justice. The new democracies raise the issue in the Latin American region, focused mainly on the fight against impunity, the amnesty laws, and the right to truth. Moreover, from Barrios Altos versus Peru precedent, it has become important, in our reality, the case Gomes Lund and others versus Brazil, in which the Inter-American Court condemned Brazil due to the disappearance of Araguaia guerrilla activists during military operations that took place in the 70's. 
With regard to vulnerable groups, the Court is very understanding and sensitive to the indigenous demands - with emphasis on the leading case - the indigenous community Mayagna Awas Tingni versus Nicaragua (2001), in which the Court recognized the rights of indigenous peoples to collective ownership of land linked to their culture, their spiritual life, their integrity and their economic survival. Apart from these, there are court decisions in regard to children's rights (Villagran Morales versus Guatemala, 1999) and women (case Gonzalez and others versus Mexico).

In the latter category, protection of social rights, it is important to reiterate the American Convention on Human Rights' limitations on this category of rights, covering only their progressive implementation of social rights (Article 26) on one side, and on the other side, the San Salvador Protocol, that provides only the rights to education and freedom association as protectable by the system of individual petitions (Article 19, paragraph 6). In any case, in the light of a dynamic and evolutionary interpretation, including the American Convention as a living instrument, the Court has been meeting these demands. Therefore, one highlights the case of Villagran Morales versus Guatemala, in which the Court stated that the right to life cannot be conceived restrictively.

On the other hand, the European Court of Human Rights deals more frequently with issues related to civil and criminal procedural safeguards, civil rights and privacy, and some social rights such as education, as shown in the table below. 
Table 5. European Court of Human Rights (ECHR, Judgments, Violations by article)

\begin{tabular}{|c|c|c|c|c|c|c|c|c|c|c|c|}
\hline Article & $\begin{array}{l}\text { Judgments (ECHR) } \\
\text { Violations by article }\end{array}$ & 2015 & 2014 & 2013 & 2012 & 2011 & 2010 & 2009 & $\begin{array}{l}\text { Total } \\
(2009- \\
2015)\end{array}$ & $\begin{array}{l}(2009- \\
2015 / \\
1959- \\
2015)\end{array}$ & $\begin{array}{l}\text { Total } \\
(1959- \\
\text { 2015) }\end{array}$ \\
\hline 2 & $\begin{array}{l}\text { Right to life - } \\
\text { deprivation of life }\end{array}$ & 23 & 25 & 33 & 36 & 70 & 54 & 71 & 312 & $68 \%$ & 458 \\
\hline 2 & $\begin{array}{l}\text { Lack of effective } \\
\text { investigation }\end{array}$ & 58 & 44 & 51 & 42 & 90 & 64 & 81 & 430 & $66 \%$ & 653 \\
\hline 3 & Prohibition of torture & 10 & 4 & 11 & 24 & 15 & 13 & 8 & 85 & $64 \%$ & 133 \\
\hline 3 & $\begin{array}{l}\text { Inhuman or degrading } \\
\text { treatment }\end{array}$ & 157 & 174 & 163 & 169 & 183 & 217 & 190 & 1253 & $75 \%$ & 1670 \\
\hline 3 & $\begin{array}{l}\text { Lack of effective } \\
\text { investigation }\end{array}$ & 88 & 55 & 67 & 99 & 89 & 74 & 64 & 536 & $81 \%$ & 662 \\
\hline 3 & Conditional violations & 12 & 15 & 12 & & & & & 39 & $100 \%$ & 39 \\
\hline 4 & $\begin{array}{l}\text { Prohibition of } \\
\text { slavery/forced labour }\end{array}$ & 1 & 0 & 0 & 2 & 0 & 2 & 0 & 5 & $83 \%$ & 6 \\
\hline 5 & $\begin{array}{l}\text { Right to liberty and } \\
\text { security }\end{array}$ & 182 & 212 & 219 & 235 & 261 & 315 & 342 & 1766 & $58 \%$ & 3053 \\
\hline 6 & Right to a fair trial & 131 & 149 & 166 & 211 & 211 & 254 & 482 & 1604 & $37 \%$ & 4329 \\
\hline 6 & Length of proceedings & 104 & 117 & 177 & 227 & 341 & 461 & 449 & 1876 & $35 \%$ & 5435 \\
\hline 6 & Non-enforcement & 45 & 47 & 69 & 42 & 89 & 89 & & 381 & $100 \%$ & 381 \\
\hline 7 & $\begin{array}{l}\text { No punishment } \\
\text { without law }\end{array}$ & 2 & 1 & 7 & 5 & 5 & 0 & 5 & 25 & $61 \%$ & 41 \\
\hline 8 & $\begin{array}{l}\text { Right to respect for } \\
\text { private and family life }\end{array}$ & 61 & 71 & 74 & 87 & 126 & 75 & 121 & 615 & $54 \%$ & 1146 \\
\hline 9 & $\begin{array}{l}\text { Freedom of thought, } \\
\text { conscience and } \\
\text { religion }\end{array}$ & 2 & 7 & 6 & 6 & 5 & 5 & 5 & 36 & $59 \%$ & 61 \\
\hline 10 & $\begin{array}{l}\text { Freedom of } \\
\text { expression. }\end{array}$ & 28 & 47 & 32 & 33 & 32 & 55 & 44 & 271 & $44 \%$ & 619 \\
\hline 11 & $\begin{array}{l}\text { Freedom of assembly } \\
\text { and association }\end{array}$ & 14 & 14 & 10 & 13 & 12 & 18 & 18 & 99 & $55 \%$ & 179 \\
\hline 12 & Right to marry & 0 & 0 & 0 & 1 & 0 & 3 & 0 & 4 & $50 \%$ & 8 \\
\hline 13 & $\begin{array}{l}\text { Right to an effective } \\
\text { remedy }\end{array}$ & 110 & 128 & 121 & 127 & 187 & 185 & 190 & 1048 & $51 \%$ & 2045 \\
\hline 14 & $\begin{array}{l}\text { Prohibition of } \\
\text { discrimination }\end{array}$ & 10 & 12 & 21 & 20 & 7 & 20 & 29 & 119 & $49 \%$ & 242 \\
\hline P1-1 & Protection of property & 94 & 98 & 107 & 124 & 155 & 199 & 384 & 1161 & $39 \%$ & 2992 \\
\hline P1-2 & Right to education & 1 & 2 & 0 & 1 & 0 & 0 & 2 & 6 & $46 \%$ & 13 \\
\hline P1-3 & Right to free elections & 12 & 5 & 2 & 9 & 3 & 9 & 2 & 42 & $53 \%$ & 79 \\
\hline \multirow[t]{2}{*}{ P1-4 } & $\begin{array}{l}\text { Right not to be tried or } \\
\text { punished twice }\end{array}$ & 5 & 4 & 1 & 0 & 1 & 1 & 3 & 15 & $75 \%$ & 20 \\
\hline & $\begin{array}{l}\text { Other Articles of the } \\
\text { Convention }\end{array}$ & 10 & 18 & 22 & 27 & 19 & 22 & 34 & 152 & $52 \%$ & 293 \\
\hline
\end{tabular}

Source: European Court of Human Rights - Statistics. https://goo.gl/okFnH [Accessed Apr. 3, 2016]. Database organized by the research group (DIRPOL/PPGD/UFPR). 
Graph 6. ECHR - Judgments (2009-2015) - Violations by article

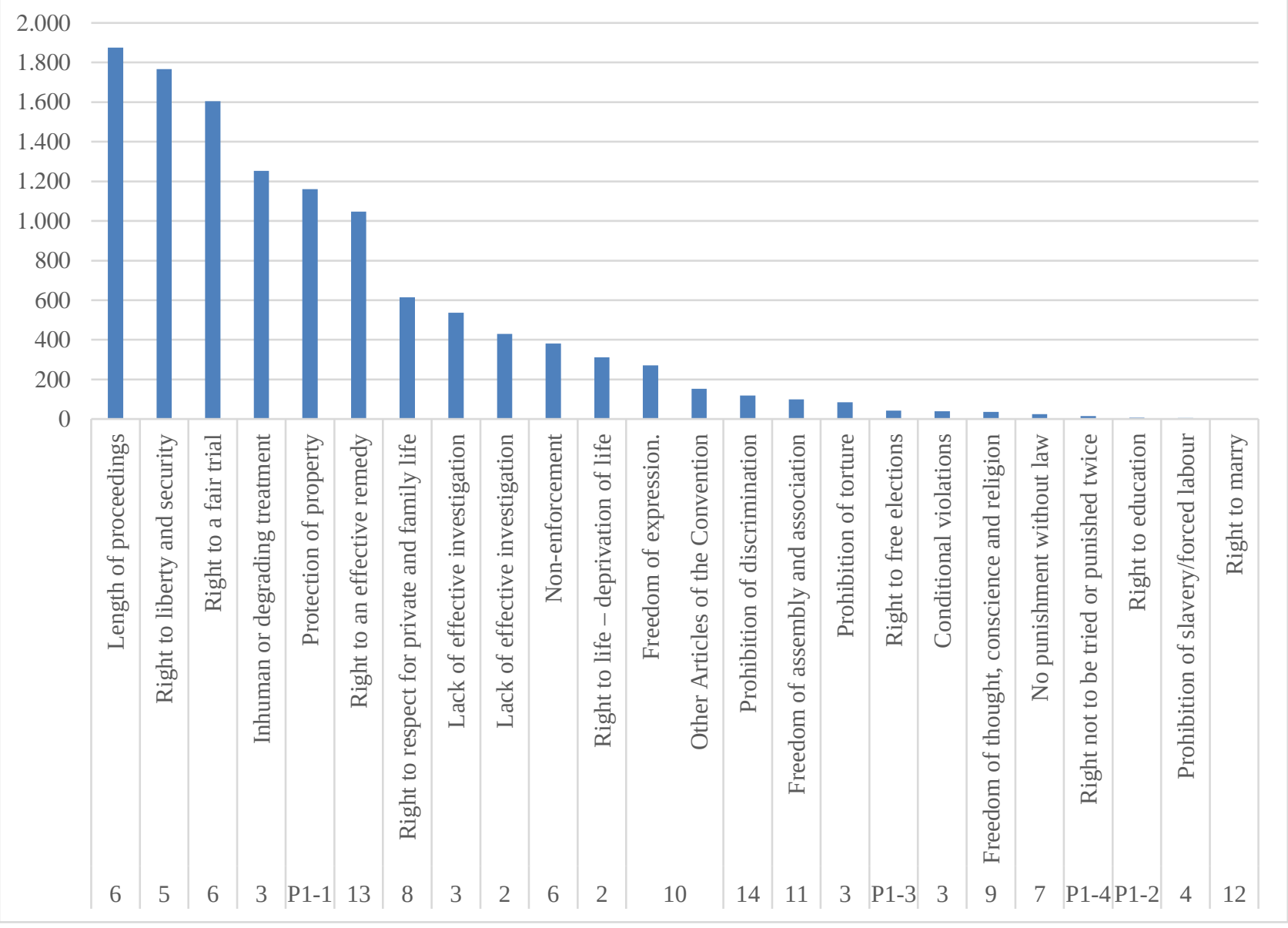

Table 6. Inter-American Court of Human Rights (IACHR) Category of demands to Court

\begin{tabular}{lcc}
\hline Category of demands to Court & $\begin{array}{c}\text { Total } \\
(\mathbf{2 0 0 6}-\mathbf{2 0 1 3})\end{array}$ & $\begin{array}{c}\mathbf{\%} \\
(\mathbf{2 0 0 6 - 2 0 1 3 )}\end{array}$ \\
\hline Final Judgments & $\mathbf{1 3 6}$ & $\mathbf{1 0 0 \%}$ \\
\hline Legacy of Political Regimes & 38 & $\mathbf{2 8 \%}$ \\
\hline Transitional Justice & 4 & $\mathbf{3 \%}$ \\
\hline Rule of law & 42 & $\mathbf{3 1 \%}$ \\
\hline Vulnerable Social Groups & 23 & $\mathbf{1 7 \%}$ \\
\hline Social Rights & 16 & $\mathbf{1 2 \%}$ \\
\hline Others & 13 & $\mathbf{1 0 \%}$ \\
\hline Precautionary Measures & $\mathbf{3 0 9}$ & $\mathbf{1 0 0 \%}$ \\
\hline Legacy of Political Regimes & 68 & $\mathbf{2 2 \%}$ \\
\hline Transitional Justice & 5 & $\mathbf{2 \%}$ \\
\hline Rule of law & 90 & $\mathbf{2 9 \%}$ \\
\hline Vulnerable Social Groups & 100 & $\mathbf{3 2 \%}$ \\
\hline Social Rights & 10 & $\mathbf{3 \%}$ \\
\hline Others & 36 & $\mathbf{1 2 \%}$ \\
\hline
\end{tabular}

Source: Inter-American Court of Human Rights - Jurisprudence. https://goo.gl/qBgcOC [Accessed Sep. 15, 2015]. Database organized by the research group (DIRPOL/PPGD/UFPR). 
Graph 7. IACHR (Final Judgments) - Category of demands to Court

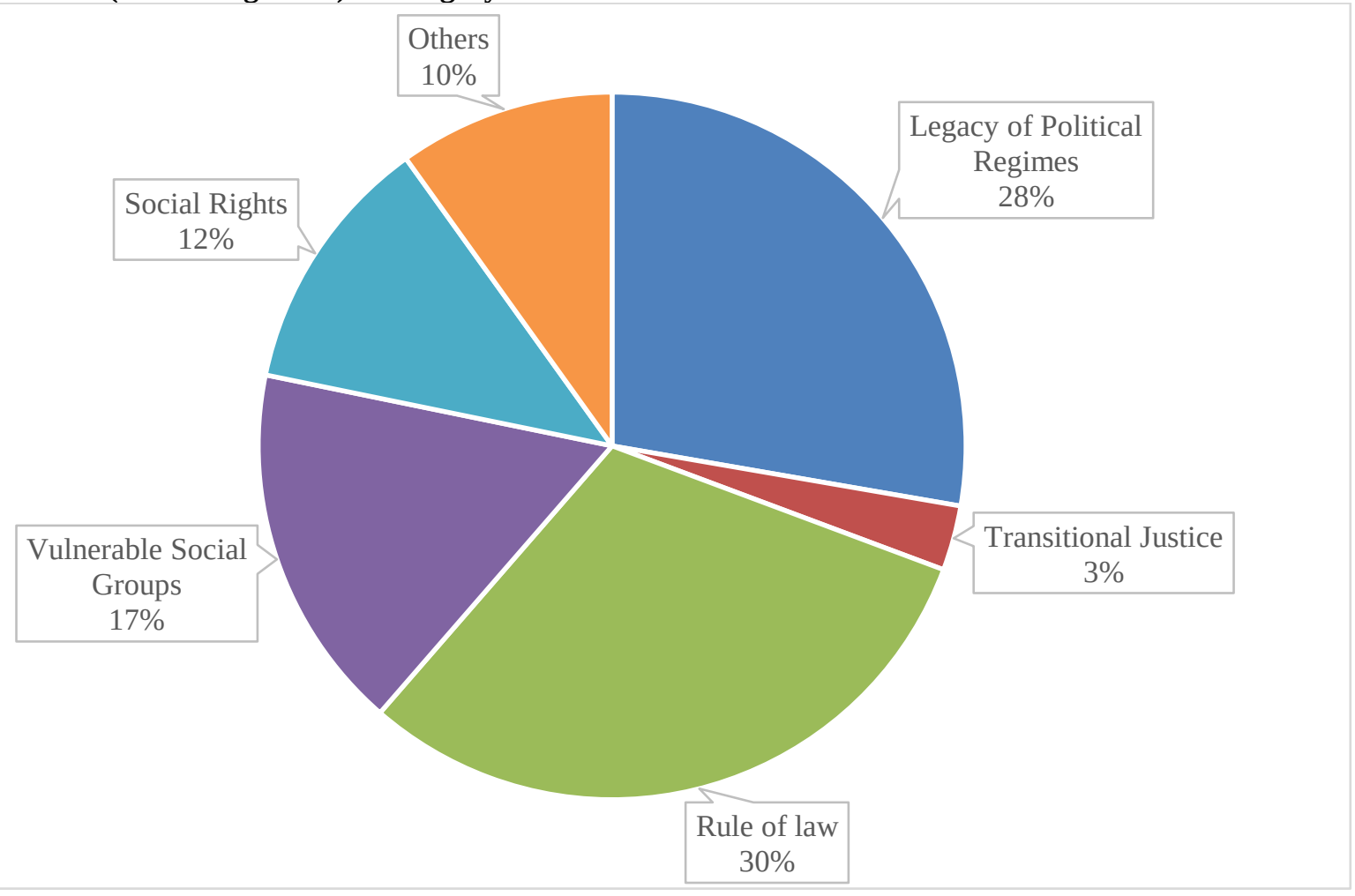

The doctrine of Flávia Piovesan analyzes the difference of contents faced by the two systems:

Under the inspiration of the individualist liberal ideology, the European Court has safeguarded the value of freedom and its projection in the sphere of private and family life, privacy, intimacy, affirming the right of any individual to develop his personality. It has faced the oppression and excessive use of authority, under the view of the reduced margin of State intervention in the field of freedoms. Based on the principle of proportionality, it has invalidated abusive state interference, which cannot be justified in a democratic society. By protecting, indirectly, social rights, it has hold that the right to privacy requires not only state the negative obligations but also positive benefits, condemning the State omission when it affronts the right to privacy - for example, due to environmental degradation caused by the company. Respect for private life - to demand negative and positive measures of state supported in individualistic liberal ideas, make up the logic and of principles to move the European Court and its case-law regarding the protection of the right to free sexual orientation, social rights and the protection of civil liberties in the fight against terrorism.

In a different context - marked by the will of authoritarian regimes and for serious and systematic violations of human rights - the Inter-American Court has ensured the protection of the right to cultural identity of vulnerable populations, requiring specific action by a dynamic and evolutionary interpretation of the American Convention conceived as a "living instrument" (such as the European Court in cases involving the protection of the right to free sexual orientation); it has dared the protection of social rights, through a broad interpretation of the right to life (endorsing the right to decent life), the necessary progressiveness of these rights, as well as through its indirect protection via civil rights; and has faced the will of state power, denouncing the "state terrorism" and affirming the primacy of law over force ${ }^{24}$.

${ }^{24}$ PIOVESAN, Flávia. Proteção dos direitos humanos: uma análise comparativa dos sistemas regional europeu e interamericano. [In the press] 
Both the European Court and the Inter-American Court face dilemmas in relation to compliance with its decisions, but for different reasons. The European system adopts the concepts of national discretion margin and fair distribution in the decisions, one understands that States must have a margin for discretion in human rights and the concept means that the European countries members need to promote full recovery of violation perpetrated in some measure. Thus, there is an advantage of this modality by respecting proper community conformation with the rights, but it reduces substantially the guarantees for vulnerable groups.

As a negative example, she cites the famous Case S.E. versus Italy. A mother sought to end the illegitimate adoption of her daughter, but the European Court hold that it could not determine the cessation of this arbitrariness. So, it was not Court's role to impose the solution on Italy State, but only recommend, prevailing a fair compensation.

In turn, the Inter-American Court of Human Rights, due to an express determination of 63 of the American Convention on Human Rights, allows a wide range of measures to the compensation or repair of human rights. On the other hand, the rate of compliance with the Court decisions by the member countries is low.

Finally, despite the reasonable differences between the two Courts, there is the degree of deference of the Inter-American Court in relation to the European Court. In the period between 2006 and 2013, out of all precedents mentioned above, 21\% of indicated Court's decisions were judged by the European Court of Human Rights, taking into account the precedents of the Inter-American Court.

\section{CONCLUSION}

The comparative study shows the importance of affiliate the experiences of each of the systems to advance together in earnings and enhance the peculiarities and to strengthen the international protection of human rights. On this necessary constitutional/international changes in today's world, teach Garapon and Allard: “Trade between the judges will intensify, as shown by the examples presented impelled by democratic sentiment or common civilizational by certain silences of positive law, the needs of the courts" 25 .

This short comparative study between Inter-American and European systems appoints tree major conclusions. First, Inter-American has been involving with basic questions of human and fundamental rights about 1 . violations that still reflect the legacy of the dictatorial regime and

\footnotetext{
${ }^{25}$ GARAPON, Antoine; ALLARD, Julie. Judges in globalization: the new revolution of law. Lisboa: Instituto Piaget,
} 2005. p. 30

Revista da Faculdade de Direito - UFPR, Curitiba, vol. 61, n. 3, set./dez. 2016, p. 67 - 89 
challenges on the strengthening of institutions and of the rule of law; 2 . issues relating to transitional justice; 3. rights violations of vulnerable groups, and, finally, 4. indirect litigation of social rights. The European Court of Human Rights deals more frequently with issues related to civil and criminal procedural safeguards, civil rights, privacy and family life. Otherwise, the European Court of Human Rights judges are open to include some social rights, such as education, in an evolutive interpretation of the liberal provisions of the Convention, as shown in the table 5 above.

Second, European Court of Human Rights made 8.137 judgments in 2009 to 2016 and InterAmerican Court of Human Rights produced 136 final judgments and granted 309 precautionary measures. Thus, there is a larger amount of judgments in European System.

Finally, the Two Courts face dilemmas concerned with compliance in their decisions. European System gives too much discretion to national authorities to observe its decisions and InterAmerican Court does not.

As a result of this diagnosis emerges the need for dialogue between the systems. Increasingly, with the integration of the East, the European Court approached the American model and problems (prisons, arbitrary use of force, due process problems, among others) and, including new demands for recognition on the agenda (same-sex marriage, for example), the Inter-American Court becomes more European. From that arises the necessity to communicate with each other, recognizing best practices and avoiding past errors, all in the light of local context.

\section{REFERENCES}

APPIAH, Kwame Anthony. Cosmopolitanism: ethics in a world of strangers. New York: W.W. Norton \& Company, 2006.

ARENDT, Hannah. As origens do totalitarismo. São Paulo: Cia das Letras, 1989.

BOGDANDY, Armin von; PIOVESAN, Flávia; ANTONIAZZI, Mariela Morales (Coord.). Estudos avançados em direitos humanos: democracia e integração jurídica: emergência de um novo direito público. São Paulo: Campus, 2012.

CANÇADO TRINDADE, Antônio Augusto. O Legado da Declaração Universal e o futuro da proteção internacional dos direitos humanos. In: AMARAL JUNIOR, Alberto; PERRONE-MOISÉS, Claudia (Org.). O cinquentenário da Declaração Universal dos Direitos do Homem. São Paulo: Edusp, 1998.

. The Inter-American System of Protection of Human Rights (1948-2005): evolution, present state and perspectives. In: Apostila do curso fundamental em inglês do Instituto Internacional dos Direitos do Homem, sessão de 4-29 de julho de 2005. 
ESQUIVEL, Efrén Vázquez; SORDO, Jaime Fernando Cienfuegos. El diálogo judicial como diálogo hermenéutico: perspectivas de los derechos humanos en el diálogo de las altas cortes y la jurisdicción interna. Revista da Faculdade de Direito UFPR, v. 61, n. 1, p. 9-41, 2016. DOI: http://dx.doi.org/10.5380/rfdufpr.v61i1.44480. Available from: https://goo.gl/oRQDHk [Accessed: June 2016].

GARAPON, Antoine; ALLARD, Julie. Judges in globalization: the new revolution of law. Lisboa: Instituto Piaget, 2005.

HENKIN, Louis. International law: politics values and functions. In: STEINER, Henry J.; ALSTON, Philip. International human rights in context. 2nd ed. Oxford: Oxford University Press, 2000.

HIRSCHL, Ran. The rise of comparative constitutional law: thoughts on substance and method. Indian Journal of Constitutional Law, p. 11-38, 2008.

INTER-AMERICAN COMISSION OF HUMAN RIGHTS. Statistics. Available from: https://goo.gl/8CSqBE [Accessed: Apr. 2016].

LAFER, Celso. A reconstrução histórica dos direitos humanos. São Paulo: Cia das Letras, 1998.

. Comércio, desarmamento e direitos humanos: reflexões sobre uma experiência diplomática. São Paulo: Paz e Terra, 1999.

MERRILLS, J. G. The Council of Europe (I): The European Convention on Human Rights. In: HANSKI, Raija; SUKSI, Markku. An Introduction to the International Protection of Human Rights. 2nd ed. Turku: Institute for Human Rights, Åbo Akademi University, 2004.

PÉREZ, Jorge Rodrigues-Zapata. The dynamic effect of the case-law of the European Court of Human Rights and the role of the constitutional courts. In: EUROPEAN COURT OF HUMAN RIGHTS. Dialogues between judges. Strasbourg: Council of Europe, 2007. Available from: https://goo.gl/nWxakh [Accessed: June 2012].

PIOVESAN, Flávia. Direitos humanos e justiça internacional. São Paulo: Saraiva, 2006.

. Direitos humanos e o direito constitucional internacional. 13. ed. São Paulo: Saraiva, 2012.

. Proteção dos direitos humanos: uma análise comparativa dos sistemas regionais europeu e interamericano. [In the press]

RAMOS, André de Carvalho. Processo internacional de direitos humanos. 4. ed. Saraiva: São Paulo, 2015.

SANTOS, Boaventura de Sousa. Por uma concepção multicultural de direitos humanos. In: Reconhecer para libertar: os caminhos do cosmopolitismo multicultural. Rio de Janeiro: Civilização Brasileira, 2003.

WILT, Harmen van der; KRSTICEVIC, Viviana. The OAS System and Human Rights. In: HANSKI, Raija; SUKSI, Markku. An introduction to the international protection of human rights. 2nd ed. Turku: Institute for Human Rights, Åbo Akademi University, 2004. 


\title{
THE INTER-AMERICAN AND EUROPEAN CONTEXTS OF HUMAN RIGHTS PROTECTION: A BRIEF COMPARATIVE ANALYSIS OF REGIONAL COURTS’ DECISIONS
}

\begin{abstract}
Regional systems of human rights are part of a complex protective system that also includes national and global instruments. One of the important advantages of regional systems in comparison with global protection instruments of human rights lies in the lower difficulty of those systems in establishing consensus on these rights. Undeniably, the Inter-American and European systems are the most structured and developed and are specific object of analysis in this paper. After a reflection on the construction of the International Law of Human Rights and the Inter-American Human Rights System, this paper presents the empirical research data of the Inter-American Court of Human Rights from 2006 to 2012. Subsequently, performs a comparison with the judgments made by the European Court of Human Rights in the 2009-2015 period. It is important to register that this article uses, besides specialized literature, a strong comparative approach between American and European Human Rights Systems and, especially, techniques of empirical legal studies with a large number (Large-N) of data. The hypothesis to be tested in this text is that American and European Systems has many peculiarities because of the cultural, legal, and historical circumstances, but a comparative study of those systems is important to understand some common problems and to analyze different ways to deal with the protection of human rights. As will be showed in this paper, the hypothesis is true because, for example, the number of processes is very diverse, but both systems have strong problems in correctly enforcing their decisions.
\end{abstract}

\section{KEYWORDS}

Human rights. Regional systems. Regional courts. Comparison. 